\title{
PERBANDINGAN SKALA NYERI PASIEN PASCA OPERASI SEKSIO SESAREA YANG DIBERIKAN MORFIN INTRATEKAL DENGAN MORFIN INTRATEKAL DITAMBAH KETOROLAK INTRAVENA
}

\author{
${ }^{1}$ Indra F. Sandy \\ ${ }^{2}$ Iddo Posangi \\ ${ }^{2}$ Harold F. Tambajong
}

\author{
${ }^{1}$ Kandidat Skripsi Fakultas Kedokteran Universitas Sam Ratulangi Manado \\ ${ }^{2}$ Bagian Anestesi Fakultas Kedokteran Universitas Sam Ratulangi Manado \\ E-mail: isandy_11_215@yahoo.com
}

\begin{abstract}
Caesarean section is one of the most common procedures performed. It is estimated that $15 \%$ of births worldwide and $21.1 \%$ of those in developed countries occur via cesarean section. Surgery causes tissue damage and pain in the abdomen. Postoperative pain is acute pain that occurs after the surgery with a rapid onset. Postoperative pain indicates damages or injuries have occurred with mild-to-severe intensity. Pharmacologic therapies that can be given is an analgesic that can be administered through several routes: parenteral, oral, rectal, transdermal, and intraspinal. This study aimed to determine the patient's postoperative pain scale for caesarean section and compared the pain scale after administration of intrathecal morphine with intrathecal morphine plus ketorolac intravena at the hour 2, 4, and 8 . This was a prospective analytical study using a cross sectional approach. Samples were 32 people. The data collected were measured by using VAS pain scale and analyzed using by independent $t$ test and Man Whitney $U$ test. The results showed that at the 2nd hours the average value (mean) pain scale after intrathecal morphine use after surgery was 2.20, while the value of morphine + ketorolac is 0.00 . At the 4th hour, the average value (mean) pain scale after intrathecal morphine use after surgery was 4.75 , while the value of morphine + ketorolac was 4.55. At the 8th hour average value (mean) pain scale after postoperative intrathecal morphine use was 7.30, while the value of morphine + ketorolac was 5.85. Conclusion: At the 2nd hour, there was a difference in scale of postoperative pain in patients of caesarean section with intrathecal morphine and morphine + ketorolac $(\mathrm{p}=0.002)$. At the 4 th, there was no difference in the pain scale postoperative caesarean section patients with intrathecal morphine and morphine + ketorolac $(p=0.363)$. At the 8th, there were differences in scale of postoperative pain in patients of caesarean section with intrathecal morphine and morphine + ketorolac $(\mathrm{p}=$ $0.001)$.
\end{abstract}

Keywords: caesarean section, scale pain, intrathecal morphine, ketorolac Intravenous

\begin{abstract}
Abstrak: Operasi sesar adalah salah satu prosedur yang paling umum dilakukan. Diperkirakan bahwa 15\% dari kelahiran seluruh dunia dan 21,1\% dari mereka di negara maju terjadi melalui operasi sesar. Tindakan pembedahan menyebabkan kerusakan jaringan dan menimbulkan nyeri pada bagian abdomen.Nyeri pasca operasi merupakan nyeri akut yang terjadi setelah proses pembedahan yang memiliki awitan yang cepat. Nyeri pasca operasi mengindikasikan kerusakan atau cedera telah terjadi dengan intensitas ringan sampai berat.Terapi farmakologis ialah analgesik yang dapat diberikan melalui rute parenteral, oral, rektal, transdermal, atau intraspinal. Penelitian ini bertujuan untuk mengetahui skala nyeri pasien pasca operasi seksio sesarea dan membandingkan skala nyeri setelah pemberian morfin intratekal dengan morfin intratekal ditambah ketorolak inttavena pada jam ke 2, 4, 8. Rancangan penelitian ini bersifat analitik prospektif dengan menggunakan pendekatan potong lintang. Sampel penelitian ini
\end{abstract}


berjumlah 32 orang. Data yang dikumpulkan diukur dengan skala nyeri VAS, kemudian data dianalisis dengan menggunakan uji independent dan uji Man Whitney U. Hasil penelitian memperlihatkan pada jam ke-2 nilai rata-rata (mean) skala nyeri setelah penggunaan morfin intratekal pasca bedah 2,20, sedangkan nilai morfin + ketorolak 0,00.Pada jam ke-4 nilai ratarata (mean) skala nyeri setelah penggunaan morfin intratekal pascabedah 4,75, sedangkan nilai morfin + ketorolak 4,55. Pada jam ke-8 nilai rata-rata (mean) skala nyeri setelah penggunaan morfin intratekal pasca bedah 7,30, sedangkan nilai morfin + ketorolak 5,85. Simpulan: Pada jam ke-2, terdapat perbedaan skala nyeri pada pasien pasca operasi seksio sesarea dengan pemberian morfin intratekal dan morfin + ketorolac $(\mathrm{p}=0,002)$. Pada jam ke-4, tidak terdapat perbedaan skala nyeri pada pasien pasca operasi seksio sesarea dengan pemberian morfin intratekal dan morfin + ketorolac $(p=0,363)$. Pada jam ke-8, terdapat perbedaan skala nyeri pada pasien pasca operasi seksio sesarea dengan pemberian morfin intratekal dan morfin + ketorolak $(p=0,001)$.

Kata kunci: seksio sesarea, skala nyeri, morfin intratekal, ketorolak intravena

Pada tahun 1979, International Association for the Study of Pain mendefinisikan nyeri sebagai "suatu pengalaman sensorik dan emosional yang tidak menyenangkan, yang berkaitan dengan kerusakan jaringan yang nyata atau yang berpotensial menimbulkan kerusakan jaringan”. Nyeri timbul akibat adanya rangsangan oleh zat-zat algesik pada reseptor nyeri yang banyak dijumpai pada lapisan superfisial kulit dan beberapa jaringan di dalam tubuh. Operasi sesar adalah salah satu prosedur yang paling umum dilakukan. Diperkirakan bahwa 15\% dari kelahiran seluruh dunia dan21,1\% dari mereka di negara majuterjadimelalui operasi sesar. Angka kejadian sesar hingga 31,9\% telah dilaporkan di Inggris pada tahun 2008 dan lebih dari 1 juta setiap tahun di Amerika Serikat saja. Terapi farmakologis yang dapat diberikan ialah analgesik yang dapat diberikan melalui rute parenteral, rute oral, rektal, transdermal, dan intraspinal. Ada tiga jenis analgesik yakni (1) Non narkotik dan Obat Anti Inflamasi Non Steroid (NSAID), (2) Analgesik narkotik atau Opiat dan (3) Obat tambahan (adjuvant) atau koanalgesik yang diberikan dengan tujuan untuk meredakan nyeri dan memperbaiki kualitas hidup pasien.

\section{METODE PENELITIAN}

Penelitian ini dilakukan pada 32 pasien seksio sesarea yang sudah melewati tahap seleksi kriteria inklusi dan eksklusi dan dibagi masing-masing 16 orang untuk kelompok morfin 0,1 mg intratekal dan kelompok morfin $0,1 \mathrm{mg}$ intratekal ditambah ketorolak $30 \mathrm{mg}$ intravena. Kesediaan pasien dan menandatangani informed consent diperlukan untuk menjadi responden penelitian.

Pengukuran skala nyeri digunakan skala nyeri Visual Analog Scale (VAS), Skala analog visual (visual analog scale/VAS) adalah cara yang paling banyak digunakan untuk menilai nyeri (Gambar 1).

Skala linier ini menggambarkan secara visual gradasi tingkat nyeri yang mungkin dialami seorang pasien. Rentang nyeri diwakili sebagai garis sepanjang $10-\mathrm{cm}$, dengan atau tanpa tanda pada tiap centimeter. Tanda pada kedua ujung garis ini dapat berupa angka atau peryataan deskriptif. Ujung yang satu mewakili tidak ada nyeri, sedangkan ujung yang lain mewakili rasa nyeri terparah yang mungkin terjadi. Skala dapat dibuat vertikal atau horizontal. Manfaat utama VAS adalah penggunaannya yang sangat mudah dan sederhana. Namun, pada periode pascabedah, VAS tidak banyak bermanfaat karena pada VAS diperlukan koordinasi visual dan motorik serta kemampuan konsentrasi. VAS juga dapat diadaptasi menjadi skala hilangnya/ reda rasa nyeri.

Pengolahan data dilakukan secara bertahap, meliputi editing, coding, tabulating dan entry. Data yang diolah dalam komputer menggunakan program SPSS for windows seri 20 dan dinyatakan dalam nilai rerata \pm simpang baku (mean \pm 
SD). Uji statistik menggunakan uji t dengan derajat kemaknaan $\mathrm{p}<0,05$.

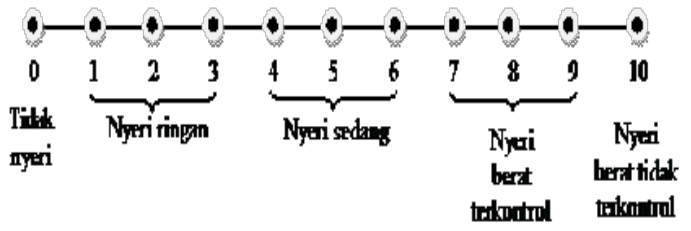

Gambar 1. Visual Analog Scale

\section{HASIL PENELITIAN}

Penelitian ini dilakukan untuk membandingkan penggunaan morfin intratekal dengan morfin + ketorolak terhadap skala nyeri pasien pasca operasi pada jam ke-2, jam ke-4 dan jam ke-8 terhadap 32 responden penelitian. Hasil data deskriptif statistik ditunjukkan pada tabel berikut (Tabel 1).

Tabel 1. Data Deskriptif Statistik Skala Nyeri Setelah Penggunaan Morfin Intratekal dan Morfin + Ketorolak Berdasarkan Jam ke-2, ke4 dan ke-8

\begin{tabular}{lcccccc}
\hline Jam & Dosis & N & Mean & SD & Min. & Max. \\
\hline \multirow{2}{*}{ ke-2 } & Morfin Intratekal & 16 & 2,20 & 1,03 & 0,00 & 3,00 \\
\cline { 2 - 6 } & Morfin + Ketorolak & 16 & 0,00 & 0,00 & 0,00 & 0,00 \\
\hline \multirow{2}{*}{ ke-4 } & Morfin Intratekal & 16 & 4,75 & 0,65 & 4,02 & 6,00 \\
\cline { 2 - 7 } & Morfin + Ketorolak & 16 & 4,55 & 0,74 & 3,00 & 6,00 \\
\hline \multirow{2}{*}{ ke-8 } & Morfin Intratekal & 16 & 7,30 & 0,56 & 7,02 & 9,00 \\
\cline { 2 - 7 } & Morfin + Ketorolak & 16 & 5,85 & 0,97 & 5,01 & 8,01 \\
\hline
\end{tabular}

Pada jam ke-2 nilai rata-rata (mean) skala nyeri setelah penggunaan morfin intratekal pasca bedah adalah 2,20, sedangkan nilai morfin + ketorolak adalah 0,00. Nilai simpangan baku ( SD = Standar Deviasi) morfin intratekal setelah pembedahan adalah 1,05, sedangkan nilai morfin + ketorolak adalah 0,00 . Nilai terendah (minimum) morfin intratekal setelah pembedahan 0,00 , dan nilai minimum morfin + ketorolak 0,00 . Nilai tertinggi (maksimum) morfin intratekal setelah pembedahan 3,00, dan nilai maximum morfin + ketorolak 0,00. Pada jam ke-4 nilai rata-rata (mean) skala nyeri setelah penggunaan morfin intratekal pasca bedah 4,75 , sedangkan nilai morfin + ketorolak 4,55. Nilai simpangan baku standar deviasi morfin intratekal setelah pembedahan 4,75, sedangkan nilai morfin + ketorolak 4,55. Nilai minimum morfin intratekal setelah pembedahan 4,00, dan nilai minimum morfin + ketorolak 3,00. Nilai maksimum morfin intratekal setelah pembedahan 6,00, dan nilai maximum morfin + ketorolak 6,00. Pada jam ke-8 nilai rata-rata (mean) skala nyeri setelah penggunaan morfin intratekal pasca bedah 7,30, sedangkan nilai morfin + ketorolak 5,85. Nilai simpangan baku standar deviasi morfin intratekal setelah pembedahan 0,57, sedangkan nilai morfin + ketorolak 0,99. Nilai minimum morfin intratekal setelah pembedahan 7,00 , dan nilai minimum morfin + ketorolak adalah 5,00. Nilai maksimum morfin intratekal setelah pembedahan 9,00, dan nilai maksimum morfin + ketorolak 8,00.

Perbandingan nilai rata-rata skala nyeri setelah penggunaan morfin intratekal dan morfin + ketorolak jam ke-2, ke-4 dan ke-8 dapat dilihat pada gambar 2 .

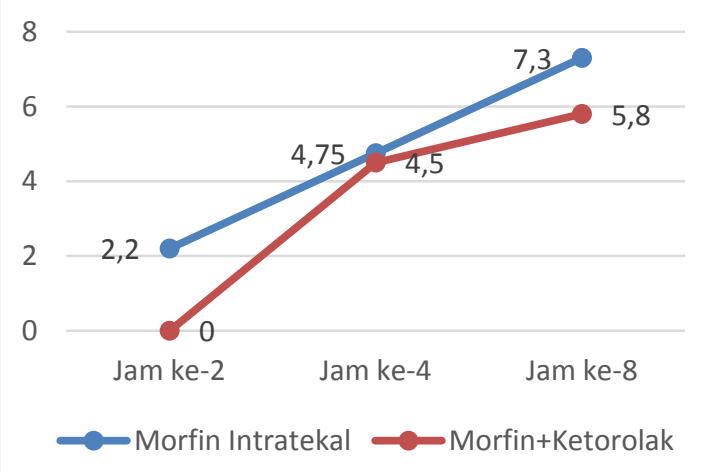

Gambar 2. Grafik Deskriptif Statistik Perbandingan Rata-rata Skala Nyeri Setelah Penggunaan Morfin Intratekal dan Morfin + Ketorolak Berdasarkan Jam ke-2, ke-4 dan ke-8

Perbandingan nilai standar deviasi setelah penggunaan morfin intratekal dan morfin + ketorolak jam ke-2, ke-4 dan ke-8 dapat dilihat pada Gambar 3.

Perbandingan nilai minimum skala nyeri setelah penggunaan morfin intratekal 
dan morfin + ketorolak jam ke-2, ke-4 dan ke-8 dapat dilihat pada Gambar 4.

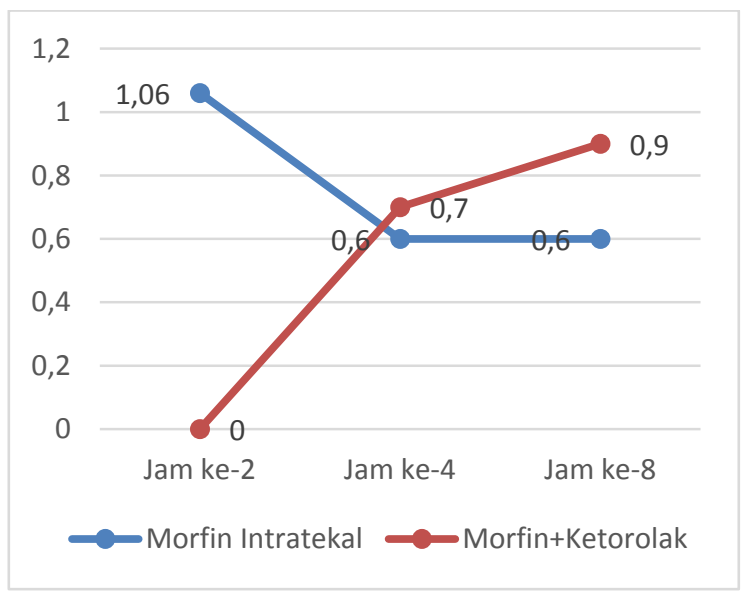

Gambar 3. Grafik Deskriptif Statistik Perbandingan Nilai Standar Deviasi Skala Nyeri Setelah Penggunaan Morfin Intratekal dan Morfin + Ketorolak Berdasarkan Jam ke-2, ke-4 dan ke-8

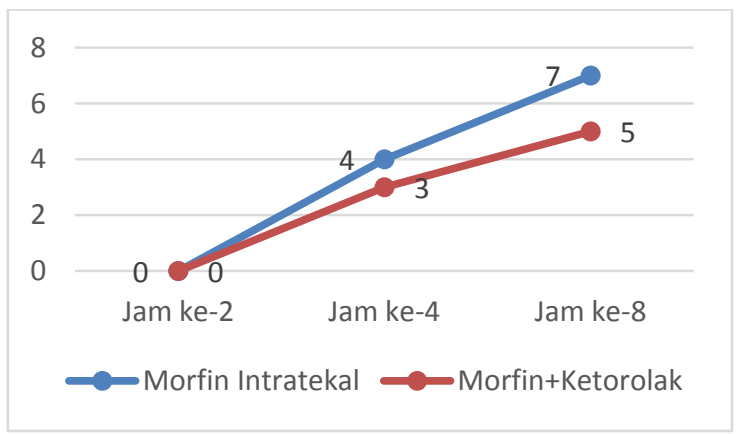

Gambar 4. Grafik Deskriptif Statistik Perbandingan Nilai Minimum Skala Nyeri Setelah Penggunaan Morfin Intratekal dan Morfin + Ketorolak Berdasarkan Jam ke-2, ke4 dan ke-8

Perbandingan nilai maximum skala nyeri setelah penggunaan morfin intratekal dan morfin + ketorolak jam ke-2, ke-4 dan ke-8 dapat dilihat pada gambar 5 berikut. Berdasarkan hasil uji normalitas dari sebaran data yang terkumpul (terlampir), diperoleh nilai signifikan masing-masing perlakuan pada jam ke-2 menunjukkan nilai $p$ sebesar 0,000, jam ke-4 menunjukkan nilai $p$ sebesar 0,000 dan jam ke-8 menunjukkan nilai $p$ sebesar 0,001 . Hasil ini menyatakan bahwa sebaran data pada kedua jenis perlakuan tidak terdistribusi secara normal $(p<0,05)$. Dengan demikian dalam pengujian statistik menggunakan salah satu analisis non parametrik yang sesuai yaitu Mann Whitney U Test.

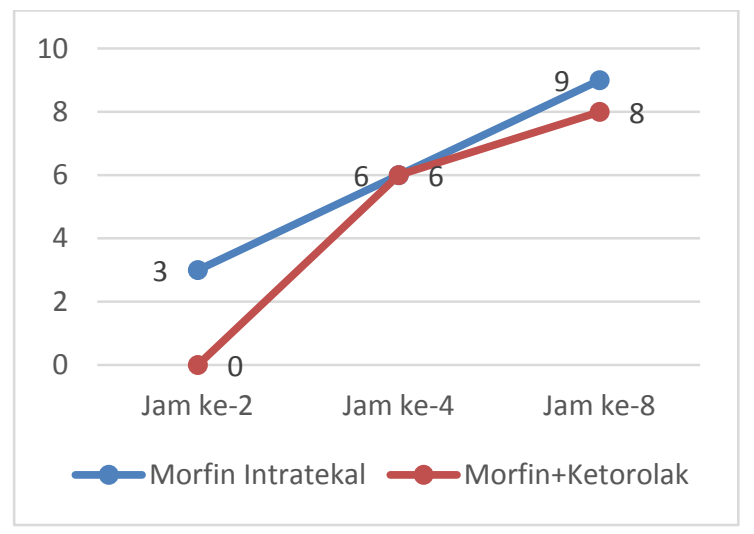

Gambar 5. Grafik Deskriptif Statistik Perbandingan Nilai Maximum Skala Nyeri Setelah Penggunaan Morfin Intratekal dan Morfin + Ketorolak Berdasarkan Jam ke-2, ke4 dan ke-8

Tabel 2. Uji Man Whitney Perbandingan Skala Nyeri Penggunaan Morfin Intratekal dan Morfin + Ketorolak Pasca Bedah seksio sesarea Berdasarkan Jam ke-2, ke-4 dan ke-8

\begin{tabular}{ccccc}
\hline \multirow{2}{*}{ Jam } & Perlakuan & $\mathrm{N}$ & $\begin{array}{c}\text { Mean } \\
\text { Ranks }\end{array}$ & Sig. \\
& & & & \\
\hline \multirow{2}{*}{ ke-2 } & Morfin Intratekal & 16 & 28,00 & \multirow{2}{*}{$p=0,002$} \\
\cline { 2 - 4 } & Morfin + Ketorolak & 16 & 14,00 & \\
\hline \multirow{2}{*}{ ke-4 } & Morfin Intratekal & 16 & 22,03 & \multirow{2}{*}{$p=0,363$} \\
\cline { 2 - 4 } & Morfin + Ketorolak & 16 & 17,98 & \\
\cline { 1 - 3 } ke-8 & Morfin Intratekal & 16 & 28,05 & \\
\cline { 2 - 3 } & Morfin + Ketorolak & 16 & 12,95 & \\
\hline
\end{tabular}

Berdasarkan Tabel 2 dapat dilihat tentang hasil uji statistik menggunakan Mann Whitney U Test (terlampir). Pada jam ke-2, nilai $p$ sebesar 0,002, jika dibandingkan dengan penggunaan $\alpha$ sebesar 5\% $(0,05)$, maka $p=0,000<0,05$, sehingga hipotesis alternatif $(\mathrm{Ha})$ diterima. Hal ini berarti bahwa terdapat perbedaan skala nyeri pada pasien pasca operasi seksio sesarea dengan pemberian morfin intratekal dan morfin + ketorolak pada jam ke-2. Pada jam ke-4, nilai $p$ sebesar 0,363, jika dibandingkan dengan penggunaan $\alpha$ 
sebesar 5\% $(0,05)$, maka $p=0,000>0,05$, sehingga hipotesis nol (H0) diterima. Hal ini berarti bahwa tidak terdapat perbedaan skala nyeri pada pasien pasca operasi seksio sesarea dengan pemberian morfin intratekal dan morfin + ketorolak pada jam ke-4. Pada jam ke-8, nilai $p$ sebesar 0,001 , jika dibandingkan dengan penggunaan $\alpha$ sebesar $5 \%(0,05)$, maka $p=0,000<0,05$, sehingga hipotesis alternatif (Ha) diterima. Hal ini berarti bahwa terdapat perbedaan skala nyeri pada pasien pasca operasi seksio sesarea dengan pemberian morfin intratekal dan morfin + ketorolak pada jam ke-8.

\section{BAHASAN}

Bahasan dalam bagian ini menjelaskan tentang perbandingan skala nyeri pada pasien pasca operasi seksio sesarea melalui pemberian morfin intratekal dan morfin + ketorolak berdasarkan jam ke-2, ke-4 dan ke-8. Berdasarkan hasil analisis statistik deskriptif, nilai mean skala nyeri pasien pasca operasi seksio sesarea pada penggunaan morfin intratekal $0,1 \mathrm{mg}$ adalah 2,20 sedangkan pada penggunaan morfin + ketorolak 30 mg adalah 0,00. Hal ini menunjukkan bahwa terdapat perbedaan skala nyeri pasda pasien pasca operasi melalui penggunaan morfin $0,1 \mathrm{mg}$ dengan morfin + ketorolak $30 \mathrm{mg}(p=0.001)$. Dalam kasus ini morfin + ketorolak dianggap lebih efektif dalam mengurangi rasa nyeri pasca bedah.

Di Amerika Serikat, lebih dari 60\% pasien dengan pembedahan nyeri sedang atau berat berikut menerima morfin. Baik Organisasi Kesehatan Dunia dan American Societyof Anestesi Task Force merekomendasikan pendekatan multimodal untuk manajemen nyeri, dengan obat anti-inflammatory drugs (NSAID) sebagai terapi awal. Penelitian ini juga bertemu endpoint sekunder sebagai nyeri yang dinilai saat istirahat berkurang sebesar 32\% pada pasien yang menerima morfin (p $<0,001)$. Tidak ada perbedaan yang signifikan antara morfin dan morfin dengan ketorolak dalam jumlah pasien dengan efek samping mual.
Pada jam ke-4 (tabel 1) dapat dilihat bahwa pada penggunaan morfin, rata-rata skala nyeri berada pada angka 4,75 sedangkan pada penggunaan morfin+ ketorolak, skala nyeri berada pada angka 4,55. Hasil analisis statistik diperoleh nilai p sebesar 0,363 sehingga $p=0,363>0,05$, hal ini menunjukkan tidak terdapat perbedaan yang signifikan perihal skala nyeri pasca operasi pada penggunaan morfin intratekal dan morfin + ketorolak.

Pada jam ke-8, terlihat perbandingan penggunaan morfin intratekal dan morfin dengan ketorolak, dimana rata-rata skala nyeri yang diperoleh adalah 7,30 pada penggunaan morfin dan 5,85 pada penggunaan morfin + ketorolak $(\mathrm{p}=$ 0,001). Hasil ini menunjukkan bahwa morfin + ketorolak lebih efektif dibandingkan morfin dalam proses analgesik pada pasien pascaoperasi seksio sesarea.

Kemampuan OAINS untuk mengatasi nyeri dapat digunakan untuk pengelolaan nyeri pascabedah. Secara umum OAINS menghambat aktivitas enzim siklooksigenase (COX) sehingga sintesis prostaglandin terhambat. Hambatan pada enzim COX-1 akan menghambat sintesis tromboksan A2 sehingga akan memengaruhi waktu perdarahan. Hasil penelitiannya menunjukkan ketorolak intravena menyebabkan waktu perdarahan lebih panjang dibandingkan deksketoprofen intravena.

Beberapa penelitian telah meneliti efektivitas analgesik ketorolac tromethamine intramuskular pada dua model nyeri pasca bedah akut; bedah umum (ortopedik, ginekologik dan abdominal) dan bedah mulut (pencabutan M3 yang mengalami impaksi). Penelitian ini merupakan uji yang dirancang paralel, dosis tunggal primer, yang membandingkan Ketorolac tromethamine dengan Meperidine (Phetidine) atau Morfin. Pada tiap model, pasien mengalami nyeri sedang hingga berat pada awal penelitian. Jika dibandingkan dengan Meperidine 50 dan $100 \mathrm{mg}$, atau Morfin 6 dan $12 \mathrm{mg}$ pada pasien yang mengalami nyeri pasca bedah, 
Ketorolac tromethamine 10, 30 dan $90 \mathrm{mg}$ menunjukkan pengurangan nyeri yang sama dengan Meperidine $100 \mathrm{mg}$ dan Morfin $12 \mathrm{mg}$. Onset aksi analgesiknya sebanding dengan Morfin. Durasi analgesia Ketorolac tromethamine $30 \mathrm{mg}$ dan $90 \mathrm{mg}$ lebih lama daripada narkotik. Berdasarkan pertimbangan efektivitas dan keamanan setelah dosis berulang, dosis $30 \mathrm{mg}$ menunjukkan indeks terapetik yang terbaik. Suatu penelitian multisenter, multi-dosis (20 dosis selama 5 hari), pasca bedah (bedah umum) membandingkan Ketorolac tromethamine $30 \mathrm{mg}$ dengan Morfin 6 dan $12 \mathrm{mg}$ dimana tiap obat hanya diberikan bila perlu. Efek analgesik keseluruhan dari Ketorolac tromethamine $30 \mathrm{mg}$ berada di antara Morfin $6 \mathrm{mg}$ dan $12 \mathrm{mg}$, walaupun perbedaan antara Ketorolac tromethamine 30 mg dan Morfin 12 mg tidak bermakna secara statistik. Tidak tampak adanya depresi napas setelah pemberian Ketorolac tromethamine pada uji klinis kontrol. Ketorolac tromethamine tidak menyebabkan konstriksi. Pada pasien pasca bedah, dibandingkan dengan plasebo : Ketorolac tromethamine tidak menyebabkan kantuk dan dibandingkan dengan Morfin, Ketorolac lebih sedikit menyebabkan kantuk.

\section{SIMPULAN}

Pada jam ke-2, terdapat perbedaan skala nyeri pada pasien pasca operasi seksio sesarea dengan pemberian morfin intratekal dan morfin + ketorolac $(\mathrm{p}=0,002)$. Pada jam ke-4, tidak terdapat perbedaan skala nyeri pada pasien pasca operasi seksio sesarea dengan pemberian morfin intratekal dan morfin + ketorolac $(\mathrm{p}=0,363)$. Pada jam ke-8, terdapat perbedaan skala nyeri pada pasien pasca operasi seksio sesarea dengan pemberian morfin intratekal dan morfin + ketorolak $(p=0,001)$.

\section{DAFTAR PUSTAKA}

1. Agus D, Triyanto. Manajemen Nyeri Dalam Suatu Tatanan Tim Medis multidisiplin. Majalah Kedokteran Atmajaya. 2004; 3: 1-13.
2. McMorrow RNC, Mhuircheartaigh RJN, Ahmed KA, Aslani A, Martin IC, Dowling $\mathbf{J J}$, et al. Comparison of Transvenous Abdominalis Plane Block vs Spinal Morphine for Pain Relief After Caesarean Section. British Journal of Anaesthesia. 2011;106:706-12.

3. Ganong WF, Jack MD, Lange D. Review of Medical Physicology. 21. 2003.

4. Farrell M, Dempsey J. Smeltzer and Bare's Textbook of Medical surgical Nursing. Edisi ke-2. 2010.

5. Aitkenhead AR. Smith G. Textbook of Anaesthesia. 2. 1990. h. 155-56.

6. Miler AR, Bogod DG, Harwood RJ. Intrathecal administration of morphine for elective Caesarean section. Journal of the Association of Anaesthetists of Great Britain and Ireland. 1996; 51: 873.

7. Ketorolac. Hexapharma Jaya a Kalbe Company. Di akses pada 22 september 2014. Available at http://www.hexpharmjaya.com/page/ ketorolac.aspx

8. Cepeda MS, Carr DB, Miranda N, Diaz A, Silvia C, Morales O. Comparison of Morphine, Ketorolac, and Their Combination for Posoperative Pain.Anesthesiology. 2005; 103: 1225-32.

9. Keat S, Bate ST. Anaesthesia on the move. Edisi ke-1. Jakarta: Tim Indeks; 2013. h. 136-37.

10.AGS Panel on Persistent Pain in Older Person. The managemant of persistent pain in older persons. $J$ Am Geriart Soc. 2002; 50: 205-24

11.Syafrudin, Hamidah. Kebidanan Komunitas. Edisi ke-1. Jakarta. 2009.

12.Syarif A, Estuningtyas A, Setiawati A, Muchtar A, Arif A, Bahry B, Suyatna FD, dkk. Farmakologi dan Terapi. Edisi ke-5. Jakarta: Badan Penerbit FKUI; 2011. h. 212-16, 244

13.Fajarini AYS. Perbandingan Efektivitas Tramadol dengan Kombinasi Tramadol + Ketorolak pada Penanganan Nyeri Pasca Seksio Sesarea. [Skripsi]. Manado: FKUNSRAT, 2013.

14.Palmer CM, Emerson S, Volgoropolous D, Alves D. Dose-Response Relationship of Intrathecal Morphine 
for Postcesarean Analgesia. Anesthesiology. 1999; 90: 441.

15. Mehta V, Langford RM. Acute pain management for opioid dependent patients. Anaesthesia. 2006; 61: 27071.

16.Dordoni PL, Ventura MD, Stefanelli A, Iannace E, Paparella P, Rocca B, et al. Effect of ketorolac, ketoprofen and nefopam on platelet function. Anasthesia. 1994; 49: 1046.

17.Rothman KJ. Declaration of Helsinki should be strengthened. BMJ 2000; 321: 442-5.

18.Spindler JS, Mehlisch D, Brown CR. Intramuscular ketorolac and morphine in the treatment of moderate to severe pain after major surgery. Pharmacotheraphy. 1990; 10: 518.
19.Smith LA, Carroll D, Edwards JE, Moore RA, McQuay HJ. Singledose ketorolac and pethidine in acute postoperative pain : Systematic review with meta-analysis. $\mathrm{Br} \quad \mathrm{J}$ Anaesth. 2000; 84: 48-58.

20.0'Hara DA, Fragen RJ, Kinzer $M$, Pemberton D. Ketorolac tromethamine and morphine sulfate for treatment of postoperative pain. Clin Pharmacol Ther. 1987; 41: 55661.

21.Price SA, Wilson LM. Patofisiologi: Konsep Klinis Proses-Proses Penyakit. Edisi ke-6. Jakarta: EGC; 2012. h. 1064.

22.Baraka A, Noueihid R, Hajj S. Intratechal Injection of Morphine for Obstetric Analgesia. 1981; 54: 136-140. 